\title{
International diversification and firm performance in the post-acquisition \\ period: A resource dependence perspective
}

\begin{abstract}
Extant research indicates that the performance effect of international diversification is debatable, and to a great extent is contingent upon a number of firm- and country-specific characteristics. We argue that a critical factor determining the behaviour of the above relationship is the event of acquisition, and more specifically the conditions under which the acquisition takes place. Drawing on resource dependence theory, this paper examines the relationship between international diversification and performance (of target firms) in the post-acquisition period. We suggest that this relationship is contingent upon the size of acquisition (volume of shares acquired), and on whether the target firm has an affiliation to a business group. Utilising a newly-created dataset comprising 164 publicly listed Indian firms for the period 2001 - 2015, we find support for our hypotheses.
\end{abstract}

Keywords: International diversification; firm performance; post-acquisition; acquisition size; business group; Indian firms

\section{Introduction}

In this study, we focus on Mergers and Acquisitions (M\&As) in India, and specifically on the role played by M\&As' size with regard to the relationship between international diversification (ID) and the performance of Indian firms. Much has been written as to the relative performance effects of M\&As. At the opposite ends of the spectrum are views that M\&As tend to constitute the product of empire building, or that they represent opportunities to build resources and capabilities, and to gain economies of scale (Cassiman, Colombo, 
Garrone, \& Veugelers, 2005; Kumar, 2009). The literature on emerging markets (EM) suggests that, owing to past technological and human capital shortfalls, organizations seeking to attain global competitiveness face a challenging catch-up game, and hence, this may be a major driver behind acquisitions (Kedia, Gaffney, \& Clampit, 2012; Luo \& Tung, 2007). However, if acquisitions are primarily about resource seeking, it is likely that their outcomes will be bound up with the size of the acquisition (as this affects the relative power of the acquired over the acquiree) and ID (as this will open up both opportunities and challenges of integration). Based on evidence from India, this study seeks to explore to what extent acquisitions involving EM (target) firms are likely to affect the relationship between ID and firm performance.

It has been argued that EM firms operate in politically and institutionally idiosyncratic environments (Wright, Filatotchev, Hoskisson, \& Peng, 2005), embedded in markets that are segmented between areas that are highly regulated, and large areas of informal sector activity (Peng, Wang, \& Jiang, 2008). Privatization and market reforms place acute challenges on firms (Chari \& Banalieva, 2015). At the same time, firms may develop context-specific managerial learning capabilities drawing on the experience of operating in a challenging institutional environment; however, such knowledge may not be particularly relevant to other settings if the firm ventures abroad (Cuervo-Cazurra, 2016).

India is one of the largest and an important EM in the world, as reflected by its BRICS membership. Although the Indian economy has grown rapidly in recent years, it still lags behind China, reflecting abiding institutional legacies and relatively weak state capabilities (Estrin \& Prevezer, 2011). Despite recent regulatory relaxations (e.g., permission for $100 \%$ investment in Indian-based airlines and up to $74 \%$ under the automatic route in brownfield pharmaceuticals), the country faces ongoing challenges in terms of infrastructure, human capital and skills development, and governance. Given this, it could be argued that the 
pressures for outward-orientated firms to catch up are particularly pronounced, and yet, owing to such contextual challenges, the promises of capability gains through acquisition may be hard to realize in practice.

As the comparative institutional analysis literature alerts us, firms venture abroad to acquire capabilities and opportunities that either complement or extend their existing ones (Morgan, 2012). Given, as we have seen, that many EM firms face challenges in their home institutional environment, ID may be particularly beneficial. Indian firms, in order to maximize the benefits stemming from the ID process, have merged with or been acquired by other firms, thus aiming to leverage financial and operational synergy. In 2016, major acquisitions took place in India. In terms of domestic acquisitions, Tata Power Renewable Energy Limited proceeded to a full acquisition of Welspun Renewable Energy Private Limited for $\$ 1,380.45 \mathrm{~m}$ : a move that can be interpreted as an attempt by the acquirer to increase its market share in the domestic renewable energy sector. In terms of cross-border (inbound) acquisitions, the Singapore firm Technologies Telemedia acquired a $74 \%$ majority stake of the Indian Tata Communications Data Centre Private Limited for $\$ 616 \mathrm{~m}$ (PwC India, 2017), aiming to further expand its global data centre network in four key locations, including bases in two of Asia's largest growth markets - India and China. Due to the different strategic motives of acquirers, we consider that not all post-M\&A performances end up profitable and beneficial for the target firms. We therefore argue that the relationship between ID endeavours of Indian firms and their performance is contingent upon the acquisition event, and more specifically on its relative size: that is, the likelihood that an Indian firm is being acquired by another firm and the size of the acquisition (volume of shares being acquired). We argue that Indian firms, due to their idiosyncratic (both institutional and managerial) background and operational context, are likely to face considerable constraints due to a substantial acquisition, and that these constraints will be 
expected to negatively affect the relationship between ID and firm performance.

This study aims to contribute to the wider literature on M\&As and the internationalization process of EM firms. First, it seeks to shed further light on the relationship between ID and firm performance, taking into consideration the likely event that Indian firms are being acquired (i.e., target firms) during the internationalization process. Analysing the relationship from a post-acquisition perspective, we contribute towards providing new insights into how EM firms respond to an acquisition event (i.e., in the postacquisition period) with regard to the ID - firm performance relationship. Second, we introduce in our study a relatively unexplored moderating effect - that of acquisition size - in the relationship between ID and firm performance in the post-acquisition period. This knowledge will provide insights on the extent to which the above relationship is contingent upon the percentage of shares acquired. We argue that the acquisition can be, for example, for the purpose of building the acquirer's reputation and gaining access to the acquiree's local market rather than for international expansion (Chung \& Alcácer, 2002). Moreover, a high level of acquired volume of shares can potentially lead to lack of integration between the two organizations, which can erode the acquiree's competitive advantage and hence its performance (Schweiger \& Goulet, 2005). Third, we contribute to the ID - firm performance literature by providing insights on when "business group affiliation" exerts negative or positive influence on the performance effect of the interaction between ID and acquisition size, specifically in the context of EM firms. This knowledge is of significant importance, since despite the fact that extant research has repeatedly examined the moderating effect of business group affiliation on the ID - firm performance relationship (e.g., Borda, Geleilate, Newburry, \& Kundu, 2017; Gaur \& Delios, 2015; Gaur \& Kumar, 2009; Singla \& George, 2013), there has been no attempt to systematically explain the inconclusiveness of the findings of this relationship. We argue that access to a business group's wide resources and 
capabilities enables acquired firms to better cope with environmental and institutional uncertainties (Khanna \& Palepu, 1997) which per se neutralize the negative effect of a large acquisition in the ID - firm performance relationship. In this study, we examine the moderating effect of simultaneous interaction of acquisition size and business group affiliation on the ID - firm performance link.

We test our conjectures on a newly created panel dataset consisting of 164 publicly listed internationalising Indian firms that have been acquired (at least once) during the period $2001-2015$ and find support for our hypotheses.

\section{Hypothesis development}

\subsection{International diversification and firm performance}

ID can be defined as a firm's “expansion beyond the borders of its home country across different countries and geographical regions" (Capar and Kotabe, 2003: 345). Throughout the years, neighbouring terms, such as ID, internationalization, geographic diversification and multinationality, have been used interchangeably in the wider international business and general management literature. In this study, we adopt the aforementioned definition provided by Capar and Kotabe (2003). ID is a notion that has been at the forefront of international business research for decades. Scholars have shown interest in exploring the various determinants of this phenomenon (e.g., Batsakis \& Mohr, 2017; Tihanyi, Ellstrand, Daily, \& Dalton, 2000; Tihanyi, Johnson, Hoskisson, \& Hitt, 2003), or even its outcomes. As regards the latter, considerably greater attention has been given to the exploration of the performance outcomes of ID (e.g., Capar \& Kotabe, 2003; Contractor, Kundu, \& Hsu, 2003; Gaur \& Kumar, 2009; Hitt, Hoskisson, \& Kim, 1997; Lu \& Beamish, 2004). The reason for this systematic focus on performance effects of ID is because the latter, along with product diversification, represents one of the key growth strategies of firms (Ansoff, 1965), and has 
been argued to have a substantial effect on firm performance.

The relationship between ID and firm performance has been widely and systematically researched, leading to contradictory results (Gaur \& Delios, 2015; Gaur \& Kumar, 2009; Jung, 1991; Qian, 1997; Siddharthan \& Lall, 1982; Singla \& George, 2013); some studies suggest that the effects change as any diversification is bedded down (Borda et al., 2017; Capar \& Kotabe, 2003; Contractor et al., 2003; Hitt et al., 1997; Lu \& Beamish, 2004). A more recent concern in the literature is whether EM firms behave any differently to their counterparts from developed markets (DM); a key difference will, as noted above, reflect a stronger focus on knowledge- and technology-seeking in the case of the former (Kedia, Gaffney, \& Clampit, 2012; Luo \& Tung, 2007). Given challenging circumstances in their country of origin, EM firms may have further reasons for internationalizing, such as the desire to diversify risk (Cuervo-Cazurra, 2016). Finally, liberal market reforms in many EM have made it much easier to venture abroad. Although firms may diversify internationally through a range of mechanisms, acquisitions pose particular challenges: they may afford access to fresh resources and capabilities, but also pose challenges of integration.

Apart from the contradictory findings with regard to the relationship between ID and firm performance, it is worth mentioning that there are a number of differences among firms, both when considering the firm-specific resources and the contextual and institutional imprints of their countries of origin. These differences have called for consideration of a contingency-based approach when it comes to studying the relationship between internationalization and firm performance (Ruigrok \& Wagner, 2004). Extant research has enlightened our knowledge through the incorporation of several moderating effects that seem to affect this relationship. In terms of firm-specific resources, research has provided evidence that intangible assets, such as technological and marketing intensity, positively moderate the internationalization - firm performance relationship (Hitt, Hoskisson, \& Ireland, 1994; Lu \& 
Beamish, 2004). ${ }^{1}$ In terms of important organization- and governance- related moderating effects, scholars have brought into attention the role of the entry mode choice, e.g., greenfield investment (Doukas \& Lang, 2003) or intra-regional concentration throughout international expansion (Qian, Khoury, Peng, \& Qian, 2010), while others have highlighted the role of power-dependence in the context of business group affiliation (Kim, Hoskisson, \& Wan, 2004).

The latter touches an important, yet under-researched moderating effect, as far as the internationalization - firm performance relationship is concerned. In our study, we draw on the logic of power-dependence, and more specifically on that of resource dependence theory (RDT) (Pfeffer \& Salancik, 1978), and argue that the volume of shares that a target firm in India gives away throughout an acquisition process will negatively moderate the ID - firm performance relationship. However, also drawing on the RDT perspective, we propose that a potential business group affiliation can alleviate this negative interaction effect between acquisition size and ID.

\subsection{The post-acquisition period in the ID - firm performance relationship}

In the previous subsection, we reviewed several empirical studies that have examined the relationship between ID and firm performance. We noted that the above-mentioned relationship, although widely and systematically researched, has so far led to contradictory results. We argued that one of the reasons for this lack of consistency in the findings is the limited consideration of a contingency-based approach. Following up on this argument, we propose that Indian firms, after they experience an acquisition event by another firm (i.e., in the post-acquisition period), will manage to improve the returns accrued from the ID activity. We provide the following arguments for this conjecture.

\footnotetext{
${ }^{1}$ For a comprehensive meta-analytic review of this relationship, please see Kirca et al. (2011).
} 
First, it can be argued that acquisitions abroad allow for the rapid diffusion of knowledge and capabilities from the parent (acquirer) to the target (acquiree) firm; inter alia, this can include expertise in operating in challenging institutional circumstances (Barkema, Shenkar, Vermeulen, \& Bell, 1997). In our case, it can be argued that Indian firms could benefit from the potentially valuable international (operational) experience of the acquirers in institutionally idiosyncratic foreign markets, and that so far, both the screening process and negative consequences stemming from the complexity of operating in challenging markets could have impeded their attempts to reap the benefits of the internationalization process.

Second, an acquisition event may further strengthen the financial positioning of the target firm through rapidly providing access to complementary assets (financial resources and other tangible assets). Indian firms are likely to face considerable financial constraints stemming from the increasingly high level of internationalization they have been experiencing in the last couple of decades. A high level of internationalization can potentially lead to financial distress, which is further intensified by the (so far) limited access to (external) capital markets in India. Acquisition can be seen as a solution to this problem, easing financial frictions in target firms (Erel, Jang, \& Weisbach, 2015), and allowing for a certain level of cross-subsidization - although not always with positive results for the parent firm (Denis, Denis, \& Yost, 2002) - and access to internal capital markets (if the acquirer is a business group).

Third, apart from the financial slack, it can be argued that Indian firms are likely to benefit from the acquirer's experiential knowledge of particular foreign markets, which can further facilitate the process of internationalization and more effectively and rapidly outweigh the costs of adaptation in the foreign market (Morosini, Shane, \& Singh, 1998). Knowledge and experience absorbed during the acquisition phase may reduce the liability of foreignness 
and offset any costs of adjustment (Dierickx \& Cool, 1989; Jiang, Beamish, \& Makino, 2014).

Based on these arguments, we expect that the acquired Indian firms will overall take advantage of the benefits stemming from the acquisition event, and as such will be more capable to reap the benefits of the internationalization process. Accordingly, we formulate the following hypothesis.

H1: In the post-acquisition period, there will be a positive relationship between Indian firms' international diversification and performance.

\subsection{The moderating effect of acquisition size}

As we have seen, one of the driving forces in the event of acquisition is the desire to access key resources of the acquiree (Ulrich \& Barney, 1984). According to Pfeffer (1976), there are three reasons why organizations proceed to M\&As: First, in order to reduce the threat of competition via acquiring a key competitor; second, to more efficiently manage interdependence in the value chain (that is, between the organization and its suppliers and buyers); and third, to increase the diversity of operations in order to decrease the level of dependence on other organizations with which it currently interacts.

However, the relative influence over the target firm will depend on whether a significant block holding or outright ownership is secured; this will impact on the level of influence and power of the acquirer over the acquiree. Based on these RDT-related rationales, we argue that the greater the percentage of shares acquired ("size of acquisition"), the more vulnerable and dependent the acquired (target) firm will be. In turn, it can be argued that greater control over the target firm may leave the latter worse off. We provide the following arguments to support our logic.

First, the acquisition of strategic assets can facilitate the acquirer to build reputation 
and gain access to the local market (Chung \& Alcácer, 2002); the target firm may simply be a vehicle to attain this, which is then discarded. This could eventually lead to exploitation of the acquiree's strategic resources and assets, with a potential shift of service towards the domestic rather than the international market.

Second, we argue that a high level of acquisition could potentially lead to inefficient or inadequate integration of one organization to another without effective clarification and management of (organizational and/or national) cultural differences to avoid cultural "clash", which can entail negative consequences for the overall value of the deal (Cartwright \& Schoenberg, 2006; Goulet \& Schweiger, 2000; Schweiger \& Goulet, 2005). Such lack of integration can lead to organizational inefficiencies, thus leading to adoption of a different internationalization strategy or even erosion of competitive advantage, and consequently to an overall negative impact on the relationship between ID and firm performance.

Overall, we argue for a negative moderating effect of acquisition size on the performance effect of ID, and based on the aforementioned arguments, we formulate the following hypothesis.

H2: In the post-acquisition period, a high volume of acquired shares will negatively moderate the relationship between Indian firms' international diversification and firm performance.

\subsection{The joint moderating effect of business group affiliation and acquisition size}

The literature on the moderating role of business group affiliation on the relationship between ID and firm performance in the context of EM firms (i.e., whether it is positive or negative) is as yet inconclusive (Gaur \& Delios, 2015; Gaur \& Kumar, 2009; Singla \& George, 2013). Business groups are defined as "a set of firms which, though legally independent, are bound together by a constellation of formal and informal ties, and are accustomed to taking 
coordinated action" (Khanna \& Rivkin, 2001: 47-48). Extant literature has suggested that business group affiliates take advantage of the fact that they are tapped into a network governance structure. This can be done in two ways. First, the affiliates can exercise leverage over valuable resources that are available in the group's network, such as access to internal capital markets, use of shared technology and recruitment of experienced management teams. Second, business groups have gained experience from operating in international markets, which in turn helps their affiliate units to cope with inefficiencies related to liability of foreignness and late mover disadvantage (Lin, Peng, Yang, \& Sun, 2009). It has been argued that this is particularly relevant to the case of Indian firms (Aulakh, Kotabe, \& Teegen, 2000) which are operating in an environment that lacks formal and informal institutions required for efficient business activities (Gaur \& Kumar, 2009).

Business groups are in a position to better cope with environmental and institutional uncertainties stemming from information asymmetry, inefficient regulatory systems, and unreliable enforcement mechanisms (Khanna \& Palepu, 1997). Due to their importance to the economy, business groups may enjoy preferential access to EM governments, which could lower the barriers to resource deployment that these firms face (Bhagwati, 1982). Moreover, financial markets are often undeveloped in EM, where weak investor protection, contract enforcement and information disclosure can make financial transactions costly. Therefore, business groups can serve as internal financial markets which help member firms to overcome constraints in raising external capital (He, Mao, Rui, \& Zha, 2013). Business groups can also act as a buffer, absorbing shocks across the group, in the case of imperfect or incomplete markets (Khanna \& Palepu, 2000a, 2000b). Again, business group affiliates hold particularly critical organizational skills and capabilities through their access to organizationwide resources (Khanna \& Palepu, 2000a). 
Based on the above arguments, we conjecture that the acquirer is likely to aim for a higher size of acquisition in order to tap into the firm- and country-specific knowledge and overall network of the business group affiliate (acquiree), thus seeking a synergistic and complementary relationship, rather than one leading to potential trade-offs. Such a synergistic relationship is likely to lead to further strengthening of the internationalization endeavours of the acquiree, putting particular emphasis on increasing the benefits of the international diversification process. Also, in the case of a sizable acquisition, acquirees affiliated with a business group will be more likely to efficiently deal with acquirers' demands and postacquisition integration plans, taking advantage of the cross-subsidization of both financial and human resources. This would eventually place the acquiree in a better negotiating position regarding the post-acquisition strategy and plans for the structure of the firm, which can be argued to have a positive impact on the ID - firm performance relationship.

Overall, we conjecture that a high level of acquired shares of business group affiliates will not be as detrimental as it is for firms which are not affiliated with a business group, for example, as far as the ID - firm performance relationship is concerned. Based on the abovementioned argumentation, we hypothesize that:

H3: In the post-acquisition period, the simultaneous presence of a high volume of acquired shares and business group affiliation strengthens the relationship between Indian firms' international diversification and performance.

Figure 1 summarizes the hypothesized relationships graphically.

\section{--- Insert Figure 1 here ---}

\section{Methodology}

\subsection{Research context, empirical setting and sample selection}

Information on our sample's firms is retrieved from the Prowess database of the Center for 
Monitoring Indian Economy (CMIE), a leading database providing financial and background information on Indian firms. There is an established body of earlier work using this dataset for a range of different purposes (e.g., Bhaumik, Estrin, \& Mickiewicz, 2016; Buckley, Munjal, Enderwick, \& Forsans, 2016; Gaur \& Delios, 2015). In order to build our dataset and achieve a sufficient level of homogeneity among the selected companies, we follow three particular steps. First, we focus on firms listed for at least a calendar year in either the Bombay Stock Exchange (BSE) or the National Stock Exchange (NSE), which has presence in all major cities in India ${ }^{2}$. The BSE is the fourth largest stock exchange in Asia, while the NSE is the $12^{\text {th }}$ largest stock exchange in the world. In total, 7,836 firms have been listed in either of these stock exchanges during the respective time period under study. Second, we narrow down our search to Indian firms which have shown international activity for at least a calendar year throughout the 15 -year period of examination. This is a core prerequisite for the inclusion of a firm in our sample, given the fact that internationalization is a key aspect in our study. Third, given our research interest in Indian firms that have been partially or wholly acquired, we identify target firms that have experienced at least one acquisition episode - that is, having some or all of their shares being acquired - during the period of examination. After dealing with the aforementioned criteria, and also given that our independent and control variables are lagged by one year, we were able to retrieve 164 firms and form an unbalanced panel dataset with 716 firm/year observations.

\subsection{Indian context}

Since its independence, India had been slow to pick up liberal market reforms-it was only in the early 1990s, facing abysmal growth and dwindling reserves, that the Indian government

\footnotetext{
${ }^{2}$ Mumbai, Chennai, Hyderabad, Ahmedabad, Delhi, and Kolkata.
} 
embarked on a series of liberal market reforms which led to the development of credit and capital markets (Bhaumik, Gangopadhyay, \& Krishnan, 2009). Prior to this, the economy was heavily regulated. With the gradual loosening of domestic controls and the relaxation of trade barriers, not only did the development process start to pick up, but also the country began to attract the attention of multinational enterprises (MNEs), with the result that foreign direct investment (FDI) that they brought in also steadily gained pace. This can be judged from the fact that FDI stock has risen from a paltry $\$ 1,657 \mathrm{~m}$ in 1990 to $\$ 16,339 \mathrm{~m}$ in 2000 , rising further to $\$ 318,502 \mathrm{~m}$ in 2016 , accounting for $14.1 \%$ of GDP. Corresponding to this, the outward FDI stock of Indian MNEs has also risen from $\$ 1,734 \mathrm{~m}$ in 2000 to $\$ 96,901 \mathrm{~m}$ in 2010 , and further to $\$ 144,134 \mathrm{~m}$ in 2016 , accounting for $6.4 \%$ of GDP and signalling an increasing importance of two-way movement of investment undertaken by overseas-based MNEs in Indian and domestic-based MNEs in overseas markets. The interface between domestic and international companies can be judged from the fact that net M\&A purchases, which averaged $\$ 1,021 \mathrm{~m}$ between 2005 and 2007 , increased to $\$ 8,581 \mathrm{~m}$ in 2016 . As a result of the increasing pace of industrial development, boosting the manufacturing and services sectors and mechanizing the agricultural sector, the per capita gross national income has climbed from $\$ 1,120$ in 1990 to $\$ 1,960$ in 2000 ; to $\$ 4,270$ in 2010 , and to $\$ 6,490$ in 2016 . Exports and imports presently stand at around 20\% of GDP (UNCTAD, 2017). This gradual prominence on the world scene has attracted the attention of researchers, as in addition to previously being a home to MNEs, Indian firms are now a gaining reputation by becoming MNEs themselves. It is an interesting phenomenon that whilst Indian firms are making inroads overseas, overseas firms are continuing to acquire stocks in Indian firms. This crossbreeding process has put Indian MNEs on a two-way learning track—gaining first-hand 'on the job' experience from overseas ventures while making use of the experience gained from their interactions with the acquirer company that has acquired shares in them. 


\subsection{Variables}

\subsubsection{Dependent, independent and moderating variables}

In order to measure our dependent variable, firm performance, we use firm profitability, thus adopting the ratio of net income to total assets (ROA) in line with previous studies (e.g., Lu \& Beamish, 2004; Vermeulen \& Barkema, 2002). ${ }^{3}$ In order to measure our independent variable, the degree of international diversification, we use the ratio of foreign sales to total sales (FSTS). This measure efficiently assesses the degree of international exposure of a firm and has been commonly proxied as a measure of ID in several empirical studies (e.g., Capar \& Kotabe, 2003; Sapienza, Autio, George, \& Zahra, 2006). ${ }^{4}$ Our first moderating variable, acquired shares, is a proxy for size of acquisition and is measured as the percentage share of total equity of the target company that the acquirer has proposed to acquire (e.g., Kedia \& Bilgili, 2015). The second moderating variable is related to business group affiliation. This is a dummy variable taking the value 1 for those target firms that are affiliated with a business group, and the value 0 otherwise (e.g., Singla \& George, 2013).

\subsubsection{Control variables}

We use a number of firm-specific variables in order to control for traditionally important determinants of internationalization and firm performance. Following other studies (e.g., Hitt et al., 1997), we control for the level of the firm's intangible assets, presumably an important facilitator of ID and firm performance (Delios \& Beamish, 2001; Lu \& Beamish, 2004). We thus introduce and measure the marketing intensity of the firm, using the ratio of marketing expenses to total sales. Further, we control for technological intensity using the ratio of R\&D expenditures to total sales (e.g., Buckley et al., 2016). Following similar studies, we use the

\footnotetext{
${ }^{3}$ We removed outliers with the restriction of data on firm performance within a range between $0 \%$ and $100 \%$.

${ }^{4}$ We removed outliers with the restriction of data on ID within a range between $0 \%$ and $100 \%$.
} 
debt to equity ratio (e.g., Chen, Cheng, He, \& Kim, 1997) to control for firms' financial distress. We also introduce firm age, calculated as the firm's year of observation minus year of inception, and two proxies for firm size: i.e., the natural logarithm of firms' total sales and total assets. Finally, we incorporate a number of dummy variables in order to control for traditionally important macroeconomic and industry effects. Specifically, and since many markets and firms were hit by the global financial crisis during the 2008 period, we expect that the volume and intensity of both domestic and cross-border M\&As, as well as the volume of trade among nations, are likely to have been influenced. To account for the effect of the financial crisis, we introduce a dummy variable (Post-2008 period) that takes the value 1 if the given firm/year observation takes place during or beyond the year 2008 (the year of the global financial crisis), and the value 0 otherwise. We also introduce a dummy variable, Acquisition episode, which takes the value 1 if the firm experienced an acquisition event in the respective firm/year observation, and the value 0 otherwise. Finally, we incorporate an industry dummy taking the value 1 for non-finance companies, and the value 0 otherwise. Table 1 describes the variables used in the study and the corresponding relevant references.

\section{--- Insert Table 1 here ---}

\subsection{Estimation method}

Due to the nature of the panel data and the presence of firm/year observations, it is necessary to eliminate any concerns related to the potential heteroskedasticity that exists between panels, as well as those related to autocorrelation within panels. Since the adoption of a simple ordinary least squares (OLS) method is not in a position to tackle the aforementioned issues, an efficient way to deal with these concerns is to adopt a generalized least squares (GLS) method, as it can be very effective in terms of dealing with cross-sectional 
heteroskedasticity and within-unit serial correlation (Greene, 2003). Also, since some of our variables do not vary over time, the decision was made to use a random-effects approach. In order to further validate this decision, we employed a Hausman test, which showed that no significant correlations exist between our independent variables and the firm-level fixed effects. We thus used a random-effects model to test our hypotheses.

\section{Results}

Table 2 portrays the pairwise correlations and descriptive statistics for our variables. The descriptive statistics show that the firms in our sample are profitable by $6.51 \%$ (ROA) and internationalize their activities by $10.03 \%$. In order to check whether multicollinearity is a potential threat to our regression estimates, we calculate the variance inflation factors (VIFs). The highest VIF score is below the commonly used threshold value of 5, and as such we conclude that there is no indication of multicollinearity. Yet, multicollinearity can result from the inclusion of interaction effects in the estimation models. For that reason, we follow the procedure suggested by Aiken and West (1991), mean-centring the respective (non-binary) variables before generating the quadratic and interaction terms. This procedure guarantees that the non-essential ill conditioning among moderating variables is sufficiently alleviated (Cohen, Cohen, West, \& Aiken, 2003).

\section{--- Insert Table 2 here ---}

Table 3 presents the random effects GLS regression estimates on the relationship between ID and firm performance in the post-acquisition period. Model 1 reports the results of the linear relationship between ID and firm performance in the post-acquisition period. H1 predicted that the ID - firm performance relationship in the post-acquisition period would be 
linearly positive. The estimates in Model 1 provide support for our conjecture, since the coefficient of ID is positive and significant $(p<0.05)$. Hypothesis 1 is thus supported.

\section{--- Insert Table 3 here ---}

Models 2 and 3 report the random effects GLS estimates on the contingent relationship between ID and firm performance in the post-acquisition period. Specifically, we suggested that the ID - firm performance relationship would be contingent upon the size of the acquisition and the business group affiliation of the firm. We focus solely on the postacquisition period, as the key moderating variable is the size of acquired shares, which presumably takes place only during an acquisition event. Model 2 reports estimates corresponding to $\mathrm{H} 2$ and the moderating effect of acquisition size on the relationship between ID and firm performance. The coefficient of the interaction term is negative and significant ( $p$ $<0.10)$, providing support for hypothesis 2 .

Model 3 introduces a triple interaction effect between ID, acquisition size and business group affiliation. Specifically, it is argued that the relationship between ID and firm performance will be moderated by the simultaneous presence of a high volume of acquired shares and business group affiliation of the firm. Model 3 tests the moderating effect of acquisition size and business group affiliation on the ID - firm performance relationship. The coefficient of the interaction term in Model 3 is positive and significant $(p<0.01)$. We thus conclude that hypothesis 3 is supported.

\subsection{Sensitivity analysis}

In order to test the sensitivity of our results, we proceed to a number of robustness tests. First, as discussed earlier, the extant empirical literature on the relationship between ID and firm 
performance has produced contradictory results. It can be argued that to a great extent, it is the country or industry context that shapes the relationship, and this is why there are a number of different views and ambiguous findings with regard to how this relationship has evolved. For that reason, and given that numerous past studies have argued and found empirical support for a quadratic relationship between ID and firm performance, we proceed to the re-estimation of our model using a quadratic term on top of the linear one. The results reveal that the linear term of ID is still positive and significant, while the quadratic term becomes insignificant. We thus fail to find support for a quadratic relationship. Second, we have already controlled for and mentioned that the global financial crisis in 2008 might have influenced the intensity of both domestic and cross-border M\&As, as well as the volume of trade among nations. For that reason, we split the sample into pre- and post-crisis, and reestimate our models. The results are consistent, while for the post-2008 period, the coefficient size and statistical significance of the moderating effects are stronger. ${ }^{5}$

\section{Discussion and conclusion}

Our study adds to the literature by shedding new light on the critical role of acquisition on the relationship between ID and firm performance in the case of Indian firms. Although the ID firm performance relationship has been examined under different contexts, such as the EM context (e.g., Aulakh et al., 2000), the services sector context (e.g., Contractor et al., 2003), and the small and medium enterprises context (e.g., Lu \& Beamish, 2001), among others, there is still no information on how the event of acquisition affects the aforementioned relationship. Specifically, our study provides new insights with regard to the question of first, how the acquisition event affects the ID - firm performance relationship; second, to what

\footnotetext{
${ }^{5}$ We would like to thank one of the anonymous reviewers for suggesting this robustness test. The results from the sensitivity analysis are available from the authors upon request.
} 
extent the acquisition size moderates the ID - firm performance relationship in the postacquisition period; and third, when "business group affiliation" exerts negative or positive influence on the performance effect of the interaction between ID and acquisition size. By taking account of the importance of acquisition as a key event in the internationalization process of the EM firm, we contribute towards advancing our knowledge on the hitherto unexplored moderating effects on the arguably well-studied, but still important, relationship between ID and firm performance. We also look at the moderating effect of business group affiliation on the interaction of the ID - firm performance relationship. Specifically, through the incorporation of a triple interaction effect, which takes into account the simultaneous presence of acquisition size and business group affiliation, we contribute towards better explaining the role of business group affiliation as far as the ID - firm performance relationship is concerned.

In Hypothesis 1, we proposed that in the post-acquisition period the relationship between ID and firm performance would be positive. Although past research has empirically examined the ID - firm performance relationship in the EM context (e.g., Aulakh et al., 2000; Borda et al., 2017; Thomas, 2006), our aim was to stress the significant impact of a potential acquisition event, and as such the overall effect that is specifically reflected on the postacquisition period. Our arguments were based on the positive role of intangible assets and financial resources sourced from the acquirer, which can outweigh the liability of foreignness and associated transaction costs of the acquiree: Indian MNEs face a catch-up game, meaning that the capture of capabilities and assets acquired is of particular importance. This finding adds an extra layer of knowledge to the ID - firm performance literature, and uncovers an additional influential factor that could presumably enrich our understanding of the contingent effect of ID on firm performance.

In Hypothesis 2, we suggested that the net benefits gained by an Indian firm (i.e. 
acquiree) through operational and financial synergy (optimally utilizing the acquirer's resources) in the post-acquisition period will be influenced by the level of acquisition size. Specifically, and drawing on RDT logic, we argued that a comparatively large size of acquisition can make the acquiree more (vulnerable and) dependent on the acquirer's resources. Our findings confirm the suggested hypothesis: a high volume of acquired shares negatively moderates the relationship between ID and firm performance in the postacquisition period. So far, there have been rather limited attempts to explain the role of acquisition size on the internationalization process of the firm in general, and on the ID performance relationship in particular. Our finding confirms the view that acquirees can certainly benefit from organizational, operational, and financial synergy through utilizing acquirers' resources, but that the benefits may be constrained by circumstances. Specifically, the acquisition of a high volume of shares can potentially result in the 'wearing off' of the acquiree's competitive advantage as a result of the over-exploitation of strategic resources and assets by the acquirer (Deng, 2009), leading to any benefits being short lived. Given that India is a rapidly growing economy with an increasingly developing middle class, it could be argued that expansion may be focused on seizing a greater share of the home market, leading to acquisitions resulting in a lesser, rather than a greater, international focus for the target firm.

In Hypothesis 3, we proposed and empirically found that the relationship between ID and firm performance will be moderated by the simultaneous presence of a high volume of acquired shares and business group affiliation; as noted above, existing research on this aspect has been thus far inconclusive. Our aim was to resolve the existing inconclusiveness through introducing a triple interaction effect that simultaneously accounts for the acquiree's business group affiliation and acquisition size during the internationalization process. We argued that the negative moderating effect that was suggested in Hypothesis 2 will not hold 
when the acquired firm is affiliated with a business group. We specifically claimed that business group affiliates possess a wider range of organizational skills and capabilities (Khanna \& Palepu, 2000a), which in turn could further mitigate the negative effects of a high level of acquisition. Firms that acquire a high volume of shares of an Indian firm which is affiliated with a business group are more likely to strategically aim to gain access to the group's complementary resources and assets, thus utilizing the potentially central position of the affiliate unit. At the same time, the acquiree, as part of a business group, still has access to an important network of knowledge and strategic assets, thus not purely being dependent on the acquirer's resources. The above can actually lead to a complementary relationship under which both the acquirer and the acquiree can benefit from the internationalization process. The findings provide support for this rationale.

\subsection{Contribution to theory}

Our study's findings contribute to existing IB research in a number of ways. First, our study extends our understanding of the EM firms' ID - performance relationship, taking into consideration the hitherto unexplored event of acquisition during the internationalization process. Through assessing the otherwise well-studied relationship between ID and firm performance from a post-acquisition perspective, our research offers new insights with regard to how Indian firms react to an acquisition event during the internationalization process. Second, we argue that RDT plays an important role in that direction and introduce a previously unexplored moderating effect: that of acquisition size. Extant research investigating the relationship between ID and firm performance has not considered this rather significant moderating effect of the size of acquisition. We thus contribute towards advancing our knowledge through introducing important and at the same time unexplored elements that tend to moderate the ID - firm performance relationship. Third, our study adds to our knowledge by offering better understanding of a well-studied moderating effect: that of 
business group affiliation on the ID - firm performance relationship (e.g., Borda et al., 2017; Gaur \& Delios, 2015; Singla \& George, 2013). The literature review showed that business group affiliation can lead to multiple interpretations as a moderator, and we argued that these interpretations will be dependent upon other important factors that should simultaneously be considered with the application of this moderating effect. In this study, we conjectured and empirically found that business group affiliation as a moderator is better explained when it is examined simultaneously with acquisition size.

Although each of the BRICS countries faces its own unique advantages and challenges, India stands out due to the size and potential of its domestic market and its very specific institutional traditions. The latter have led to poorly coupled institutional arrangements, erratic state support and industrial policies, uneven regulation, and the unequal allocation of skills; this, coupled with market liberalization, makes the need for Indian firms to "catch up" particularly pressing. At the same time, this study reveals that, whilst holding the potential to rapidly extend organizational resources, acquisitions bring with them risks of their own. A desire to fully capture the capabilities of target firms may result in the latter losing their ability to generate new ones; if each firm embodies a unique set of resources, then it is easy for an outsider to misjudge them, or to misunderstand the basis under which they are generated. However, the risks seem to be somewhat mitigated by ID: firms which straddle national boundaries may gain competitive advantages and capabilities through inserting themselves into multiple production regimes (Morgan, 2012). This allows not only for risks to be mitigated, but also for potential complementarities, using success in one area to advance it in another, and to compensate for challenges and weaknesses in a particular locale.

\subsection{Managerial Implications}

The general picture of our analysis shows that the firms studied weathered the storm of the 
financial crisis of 2007-8, during which FDI flows continued to grow and were in the region of $\$ 27$ b in $2008-9$, displaying investor confidence in the country. Our sensitivity analysis provides support for this conjecture, given the fact that the coefficient size and levels of significance were strengthened, rather than weakened, during and beyond the financial crisis. Paradoxically, part of the sustained confidence of MNEs in India is the result of India's highly regulated, rather conservative financial system, which does not allow bank deposits to enter speculative activities. India continued to grow at $6.7 \%$, and as our data shows, the return on assets deployed by firms studied during this period averaged $6.51 \%$ and the internationalization of their activities averaged $10.03 \%$.

Our study points to a number of interesting implications for managers of both acquirers and acquirees strategizing to expand by way of acquiring or merging with other firms respectively. Our study's findings can be utilized by EM firms' managers in general, and Indian firms' managers in particular, in order to assess the extent to which their firms' performance, as a result of the ID process, is influenced negatively or positively by a potential acquisition event. Before deciding on a likely acquisition event of their firm, managers could draw on our findings in order to assess the benefits or costs that a high level of acquisition can entail for their firm's performance and their ID aspirations. In a similar vein, managers whose firms are affiliated with a business group can potentially plan their post-acquisition strategy in order to ensure that the net benefits stemming from the ID - firm performance relationship are not weakened by a potentially high level of acquisition. The lesson for senior managers in Indian firms is that they should continue to hold confidence in the system and negotiate deals with foreign firms as equal partners even in times of adversity. Managers could also leverage the finding that a large acquisition would lead to enhanced performance when they are affiliated to a business group. 


\subsection{Limitations and future directions}

While our study used data covering a large number of EM firms, and also utilized a number of independent and control variables and tested the hypotheses over a 15-year period, there are three important limitations that need to be highlighted. First, although the information derived from the database was rich with regard to the EM firms (acquirees), our study does not account for the characteristics of the acquirer. Our findings could have been further strengthened if the acquirer's background characteristics had been included in the study. This was not possible in the present work due to data restrictions. Second, due to lack of information, we were not able to control for important characteristics of the acquiree, such as the effect of cultural distance, prior international experience, and mode of internationalization. Third, our study is limited to investigating the behaviour of firms originating in a single EM, namely India.

Although we are confident that the results would be applicable to fellow EM with similar attributes, future studies could emulate our work with regard to additional EM to substantiate or cross check the findings. Further, future research could draw on our study's findings and theoretical context in order to explain how the relationship between ID and firm performance in the post-acquisition period is moderated by the characteristics of the acquirer, or even to what extent potential disparities between acquirers and acquirees with regard to their firm- and/or country-level characteristics could influence the aforementioned relationship.

\section{References}

Aiken, L. S., \& West, S. G. (1991). Multiple regression: Testing and interpreting interactions. Newbury Park, CA: Sage.

Ansoff, I. H. (1965). Corporate strategy: An analytic approach to business policy for growth and expansion. New York: McGraw-Hill. 
Aulakh, P., Kotabe, M., \& Teegen, H. (2000). Export strategies and performance of firms from emerging economies: Evidence from Brazil, Chile, and Mexico. Academy of Management Journal, 43(3), 342-361.

Barkema, H. G., Shenkar, O., Vermeulen, F., \& Bell, J. H. J. (1997). Working abroad, working with others: How firms learn to operate international joint ventures. Academy of Management Journal , 40(2), 426-442.

Batsakis, G., \& Mohr, A. T. (2017). Revisiting the relationship between product diversification and internationalization process in the context of emerging market MNEs. Journal of World Business, 52(4), 564-577.

Bhagwati, J. N. (1982). Directly Unproductive, Profit-Seeking (DUP) Activities. Journal of Political Economy, 90(5), 988-1002.

Bhaumik, S. K., Estrin, S., \& Mickiewicz, T. (2016). Ownership identity, strategy and performance: Business group affiliates versus independent firms in India. Asia Pacific Journal of Management, 34(2), 1-31.

Bhaumik, S. K., Gangopadhyay, S., \& Krishnan, S. (2009). Reforms and entry: Some evidence from the Indian manufacturing sector. Review of Development Economics, 13(4), 658-672.

Borda, A., Geleilate, J.-M. G., Newburry, W., \& Kundu, S. K. (2017). Firm internationalization, business group diversification and firm performance: The case of Latin American firms. Journal of Business Research, 72, 104-113.

Buckley, P. J., Munjal, S., Enderwick, P., \& Forsans, N. (2016). Cross-border acquisitions by Indian multinationals: Asset exploitation or asset augmentation? International Business Review, 25(4), 986-996.

Capar, N., \& Kotabe, M. (2003). The relationship between international diversification and performance in service firms. Journal of International Business Studies, 34(4), 345-355. 
Cartwright, S., \& Schoenberg, R. (2006). Thirty years of mergers and acquisitions research: Recent advances and future opportunities. British Journal of Management, 17(S1), S1S5.

Cassiman, B., Colombo, M. G., Garrone, P., \& Veugelers, R. (2005). The impact of M\&A on the R\&D process: An empirical analysis of the role of technological- and marketrelatedness. Research Policy, 34(2), 195-220.

Chari, M. D. R., \& Banalieva, E. R. (2015). How do pro-market reforms impact firm profitability? The case of India under reform. Journal of World Business, 50(2), 357367.

Chen, P. C. J., Cheng, A. C. S., He, J., \& Kim, J. (1997). An investigation of the relationship between international activities and capital structure. Journal of International Business Studies, 28(3), 563-577.

Chung, W., \& Alcácer, J. (2002). Knowledge seeking and location choice of foreign direct investment in the United States. Management Science, 48(12), 1534-1554.

Cohen, J., Cohen, P., West, S. G., \& Aiken, L. S. (2003). Applied multiple regression/correlation analysis for the behavioral sciences. Abingdon: Routledge.

Contractor, F. J., Kundu, S. K., \& Hsu, C. C. (2003). A three-stage theory of international expansion: The link between multinationality and performance in the service sector. Journal of International Business Studies, 34(1), 5-18.

Cuervo-Cazurra, A. (2016). Multilatinas as sources of new research insights: The learning and escape drivers of international expansion. Journal of Business Research, 69(6), 1963-1972.

Delios, A., \& Beamish, P. (2001). Survival and profitability: The roles of experience and intangible assets in foreign subsidiary performance. Academy of Management Journal, 44(5), 1028-1038. 
Deng, P. (2009). Why do Chinese firms tend to acquire strategic assets in international expansion? Journal of World Business, 44(1), 74-84.

Denis, D. J., Denis, D. K., \& Yost, K. (2002). Global diversification, industrial diversification , and firm value. The Journal of Finance, 57(5), 1951-1979.

Dierickx, I., \& Cool, K. (1989). Asset stock accumulation and sustainability of competitive advantage. Management Science, 35(12), 1504-1511.

Doukas, J. A., \& Lang, L. H. P. (2003). Foreign direct investment, diversification and firm performance. Journal of International Business Studies, 34(2), 153-172.

Erel, I., Jang, Y., \& Weisbach, M. S. (2015). Do acquisitions relieve target firms’ financial constraints? The Journal of Finance, 70(1), 289-328.

Estrin, S., \& Prevezer, M. (2011). The role of informal institutions in corporate governance: Brazil, Russia, India, and China compared. Asia Pacific Journal of Management, 28(1), $41-67$.

Gaur, A., \& Delios, A. (2015). International diversification of emerging market firms: The role of ownership structure and group affiliation. Management International Review, 55(2), 235-253.

Gaur, A. S., \& Kumar, V. (2009). International diversification, business group affiliation and firm performance: Empirical evidence from India. British Journal of Management, 20(2), 172-186.

Goulet, P. K., \& Schweiger, D. M. (2000). Integrating mergers and acquisitions: An international research review. In Advances in Mergers and Acquisitions (Vol. 1, pp. 6191). Bingley, UK: Emerald Group Publishing Limited.

Greene, W. H. (2003). Econometric analysis (Fifth edition). Upper Saddle River, NJ.: Prentice Hall.

He, J., Mao, X., Rui, O. M., \& Zha, X. (2013). Business groups in China. Journal of 
Corporate Finance, 22, 166-192.

Hitt, M., Hoskisson, R., \& Ireland, R. (1994). A mid-range theory of the interactive effects of international and product diversification on innovation and performance. Journal of Management, 20(2), 297-326.

Hitt, M., Hoskisson, R., \& Kim, H. (1997). International diversification: Effects on innovation and firm performance in product-diversified firms. Academy of Management Journal, 40(4), 767-798.

Jiang, R. J., Beamish, P. W., \& Makino, S. (2014). Time compression diseconomies in foreign expansion. Journal of World Business, 49(1), 114-121.

Jung, Y. (1991). Multinationality and profitability. Journal of Business Research, 23(2), 179187.

Kedia, B., Gaffney, N., \& Clampit, J. (2012). EMNEs and knowledge-seeking FDI. Management International Review, 52(2), 155-173.

Kedia, B. L., \& Bilgili, T. V. (2015). When history matters: The effect of historical ties on the relationship between institutional distance and shares acquired. International Business Review, 24(6), 921-934.

Khanna, T., \& Palepu, K. (1997). Why focused strategies may be wrong for emerging markets. Harvard Business Review, 75, 41-54.

Khanna, T., \& Palepu, K. (2000a). Is group affiliation profitable in emerging markets? An analysis of diversified Indian business groups. The Journal of Finance, 55(2), 867-891.

Khanna, T., \& Palepu, K. (2000b). The future of business groups in emerging markets: Longrun evidence from Chile. Academy of Management Journal , 43(3), 268-285.

Khanna, T., \& Rivkin, J. W. (2001). Estimating the performance effects of business groups in emerging markets. Strategic Management Journal, 22(1), 45-74.

Kim, H., Hoskisson, R. E., \& Wan, W. P. (2004). Power dependence, diversification strategy, 
and performance in keiretsu member firms. Strategic Management Journal, 25(7), 613636.

Kirca, A. H., Hult, G. T. M., Roth, K., Cavusgil, T. S., Morys, P. Z., Akdeniz, B. M., ... White, R. C. (2011). Firm-specific assets, multinationality, and financial performance: A meta-analytic review and theoretical integration. Academy of Management Journal, $54(1), 47-72$.

Kumar, N. (2009). How emerging giants are rewriting the rules of M\&A. Harvard Business Review, 87(5), 115-121.

Lin, Z. J., Peng, M. W., Yang, H., \& Sun, S. L. (2009). How do networks and learning drive M\&As? An institutional comparison between China and the United States. Strategic Management Journal, 30(10), 1113-1132.

Lu, J., \& Beamish, P. (2001). The internationalization and performance of SMEs. Strategic Management Journal, 22(6/7), 565-586.

Lu, J., \& Beamish, P. (2004). International diversification and firm performance: The SCurve hypothesis. Academy of Management Journal, 47(4), 598-609.

Luo, Y., \& Tung, R. L. (2007). International expansion of emerging market enterprises: A springboard perspective. Journal of International Business Studies, 38, 481-498.

Mergers and acquisitions: The evolving Indian landscape. (2017).

Morgan, G. (2012). International business, multinationals and national business systems. In G. Wood \& M. Demirbag (Eds.), Handbook of institutional approaches to international business. Cheltenham: Edward Elgar.

Morosini, P., Shane, S., \& Singh, H. (1998). National cultural distance and cross-border acquisition performance. Journal of International Business Studies, 29(1), 137-158.

Peng, M. W., Wang, D. Y. L., \& Jiang, Y. (2008). An institution-based view of international business strategy: a focus on emerging economies. Journal of International Business 
Studies, 39(5), 920-936.

Pfeffer, J. (1976). Beyond management and the worker: The institutional function of management. Academy of Management Review , 1(2), 36-46.

Pfeffer, J., \& Salancik, G. R. (1978). The external control of organizations: A resource dependence approach. New York: Harper and Row Publishers.

Qian, G. (1997). Assessing product-market diversification of U.S. firms. MIR: Management International Review, 37(2), 127-149.

Qian, G., Khoury, T. A., Peng, M. W., \& Qian, Z. (2010). The performance implications of intra- and inter-regional geographic diversification. Strategic Management Journal, 31(9), 1018-1030.

Ruigrok, W., \& Wagner, H. (2004). Internationalization and firm performance: Meta-analytic review and future research directions. In Annual Meeting of the Academy of International Business. Stockholm, Sweden.

Sapienza, H. J., Autio, E., George, G., \& Zahra, S. A. (2006). A capabilities perspective on the effects of early internationalization on firm survival and growth. Academy of Management Review, 31(4), 914-933.

Schweiger, D. M., \& Goulet, P. K. (2005). Facilitating acquisition integration through deeplevel cultural learning interventions: A longitudinal field experiment. Organization Studies, 26(10), 1477-1499.

Siddharthan, N. S., \& Lall, S. (1982). The recent growth of the largest US miltinationals. Oxford Bulletin of Economics and Statistics, 44(1), 1-13.

Singla, C., \& George, R. (2013). Internationalization and performance: A contextual analysis of Indian firms. Journal of Business Research, 66(12), 2500-2506.

Thomas, D. E. (2006). International diversification and firm performance in Mexican firms: A curvilinear relationship? Journal of Business Research, 59(4), 501-507. 
Tihanyi, L., Ellstrand, A. E., Daily, C. M., \& Dalton, D. R. (2000). Composition of the top management team and firm international diversification. Journal of Management, 26(6), $1157-1177$.

Tihanyi, L., Johnson, R. A., Hoskisson, R. E., \& Hitt, M. A. (2003). Institutional ownership differences and international diversification: The effects of boards of directors and technological opportunity. Academy of Management Journal, 46(2), 195-211.

Ulrich, D., \& Barney, J. B. (1984). Perspectives in organizations: Resource dependence, efficiency, and population. Academy of Management Review , 9(3), 471-481.

UNCTAD. (2017). World Investment Report. Geneva.

Vermeulen, F., \& Barkema, H. (2002). Pace, rhythm, and scope: Process dependence in building a profitable multinational corporation. Strategic Management Journal, 23(7), $637-653$.

Wright, M., Filatotchev, I., Hoskisson, R. E., \& Peng, M. W. (2005). Strategy research in emerging economies: Challenging the conventional wisdom. Journal of Management Studies, 42(1), 1-33. 
Figure 1. Research model.

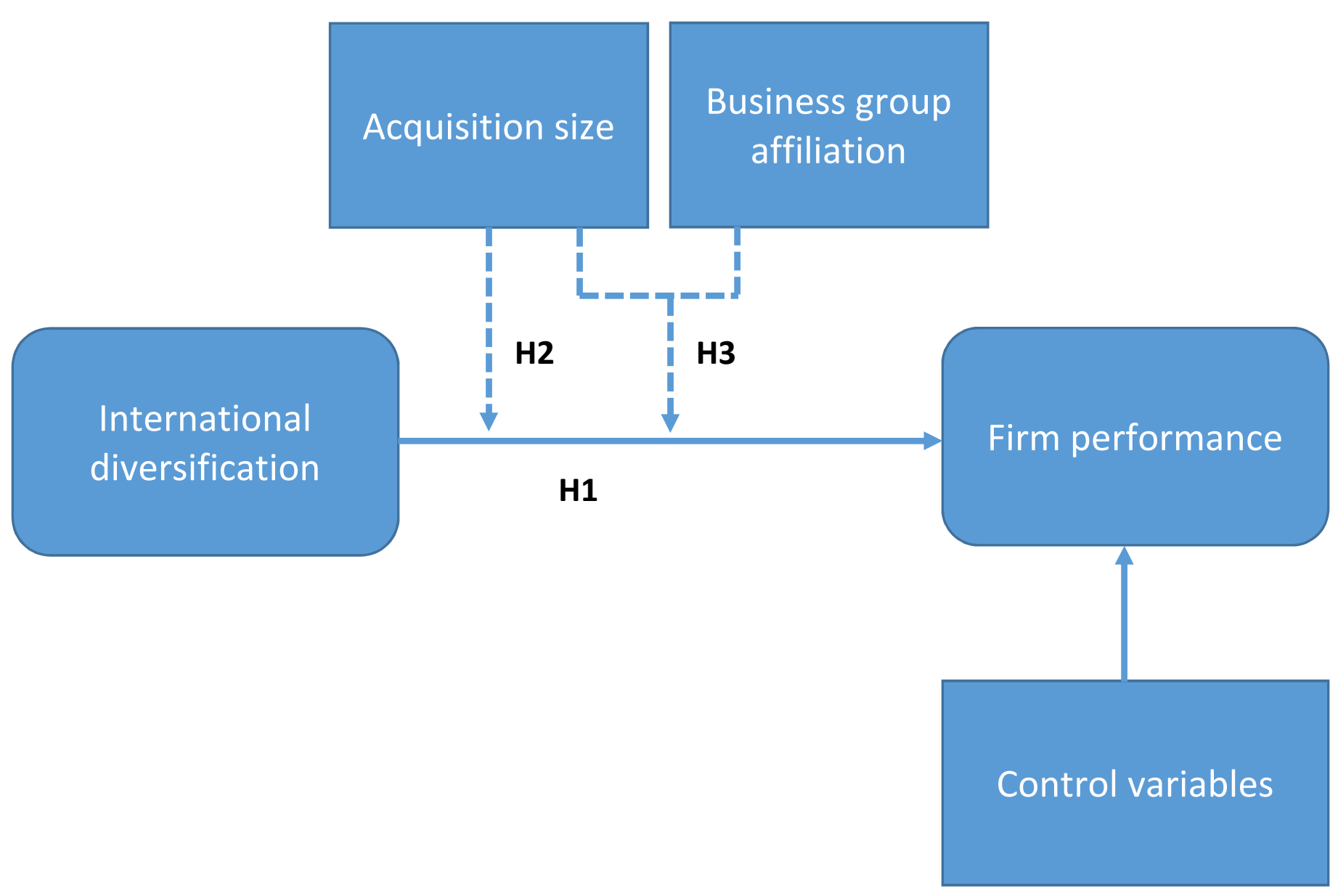


Table 1. Variables, definitions and academic sources

\begin{tabular}{|c|c|c|}
\hline Variable & Definition & References \\
\hline Firm performance & Percentage ratio of net income to total assets & $\begin{array}{l}\text { Lu \& Beamish (2004), } \\
\text { Vermeulen \& Barkema } \\
\text { (2002) }\end{array}$ \\
\hline $\begin{array}{l}\text { International } \\
\text { diversification }\end{array}$ & Percentage ratio of foreign sales to total sales & $\begin{array}{l}\text { Capar and Kotabe (2003), } \\
\text { Sapienza et al. (2006) }\end{array}$ \\
\hline Acquired Shares & $\begin{array}{l}\text { Percentage share of total equity of target } \\
\text { company that the acquirer has proposed to } \\
\text { acquire }\end{array}$ & Kedia and Bilgili (2015) \\
\hline Business group & $\begin{array}{l}\text { Dummy variable taking the value } 1 \text { for those } \\
\text { firms affiliated with a business group }\end{array}$ & $\begin{array}{l}\text { Gaur and Delios (2015), } \\
\text { Singla and George (2013) }\end{array}$ \\
\hline Marketing intensity & $\begin{array}{l}\text { Percentage ratio of marketing expenditure to } \\
\text { total sales }\end{array}$ & Buckley et al. (2016) \\
\hline $\begin{array}{l}\text { Technological } \\
\text { intensity }\end{array}$ & $\begin{array}{l}\text { Percentage ratio of } \mathrm{R} \& \mathrm{D} \text { expenditure to total } \\
\text { sales }\end{array}$ & Buckley et al. (2016) \\
\hline Debt/equity ratio & Percentage ratio of debt to total equity & Chen et al. (1997) \\
\hline Age & $\begin{array}{l}\text { Firm's year of observation minus year of } \\
\text { inception }\end{array}$ & Bhaumik et al. (2016) \\
\hline (ln)Sales & Natural logarithm of firm's total sales & Gaur and Kumar (2009) \\
\hline (ln)Assets & Natural logarithm of firm's total assets & Gaur and Delios (2015) \\
\hline \multicolumn{3}{|l|}{ Dummy variables } \\
\hline Post-2008 period & $\begin{array}{l}\text { Dummy variable taking the value } 1 \text { if the given } \\
\text { firm/year observation takes place during or } \\
\text { beyond the year } 2008 \text {, and the value } 0 \text { otherwise }\end{array}$ & \\
\hline Acquisition episode & $\begin{array}{l}\text { Dummy variable taking the value } 1 \text { if the firm } \\
\text { experienced an acquisition in the respective } \\
\text { firm/year observation, and the value } 0 \text { otherwise }\end{array}$ & \\
\hline Industry dummy & $\begin{array}{l}\text { Dummy variable taking the value } 1 \text { for non- } \\
\text { finance companies }\end{array}$ & \\
\hline
\end{tabular}


Table 2. Pair-wise correlations and descriptive statistics

\begin{tabular}{|c|c|c|c|c|c|c|c|c|c|c|c|c|c|c|c|c|c|c|}
\hline & & 1 & 2 & 3 & 4 & 5 & 6 & 7 & 8 & 9 & 10 & 11 & 12 & 13 & 14 & 15 & 16 & 17 \\
\hline 1 & ROA & 1.00 & & & & & & & & & & & & & & & & \\
\hline 2 & FSTS & 0.03 & 1.00 & & & & & & & & & & & & & & & \\
\hline 3 & Acquired shares $(\%)$ & 0.06 & 0.02 & 1.00 & & & & & & & & & & & & & & \\
\hline 4 & $\begin{array}{l}\text { FSTS x Acquired shares } \\
(\%)\end{array}$ & 0.01 & 0.37 & 0.39 & 1.00 & & & & & & & & & & & & & \\
\hline 5 & $\begin{array}{l}\text { FSTS x Business group } \\
\text { affiliation }\end{array}$ & 0.02 & 0.50 & 0.00 & 0.14 & 1.00 & & & & & & & & & & & & \\
\hline 6 & $\begin{array}{l}\text { Acquired shares }(\%) \mathrm{x} \\
\text { Business group affiliation }\end{array}$ & 0.07 & -0.04 & 0.66 & 0.13 & 0.06 & 1.00 & & & & & & & & & & & \\
\hline 7 & $\begin{array}{l}\text { FSTS x Acquired shares } \\
(\%) \times \text { Business group } \\
\text { affiliation }\end{array}$ & 0.02 & 0.17 & 0.23 & 0.46 & 0.35 & 0.34 & 1.00 & & & & & & & & & & \\
\hline 8 & Business group affiliation & 0.02 & -0.22 & -0.05 & -0.09 & 0.21 & 0.23 & 0.08 & 1.00 & & & & & & & & & \\
\hline 9 & Marketing intensity & -0.03 & -0.03 & 0.02 & 0.00 & -0.04 & -0.01 & -0.02 & -0.12 & 1.00 & & & & & & & & \\
\hline 10 & Technological intensity & 0.07 & -0.05 & -0.05 & -0.03 & -0.03 & -0.02 & 0.00 & -0.04 & 0.08 & 1.00 & & & & & & & \\
\hline 11 & Debt/equity & -0.06 & -0.02 & -0.01 & 0.00 & 0.00 & -0.01 & 0.01 & -0.06 & -0.01 & -0.03 & 1.00 & & & & & & \\
\hline 12 & Age & -0.04 & 0.15 & -0.03 & -0.01 & -0.02 & -0.02 & -0.01 & -0.08 & 0.04 & -0.02 & -0.01 & 1.00 & & & & & \\
\hline 13 & (ln)Sales & 0.03 & -0.09 & 0.01 & -0.04 & 0.00 & 0.16 & 0.01 & 0.39 & -0.22 & -0.05 & -0.02 & -0.05 & 1.00 & & & & \\
\hline 14 & (ln)Assets & -0.09 & -0.15 & 0.01 & -0.07 & 0.01 & 0.15 & 0.01 & 0.36 & 0.04 & -0.06 & 0.09 & -0.06 & 0.81 & 1.00 & & & \\
\hline 15 & Post-2008 period & -0.23 & 0.06 & -0.06 & 0.00 & -0.03 & -0.07 & 0.01 & -0.06 & 0.00 & -0.04 & -0.08 & 0.03 & 0.06 & 0.08 & 1.00 & & \\
\hline 16 & Acquisition episode & 0.02 & 0.03 & 0.63 & 0.25 & 0.02 & 0.45 & 0.14 & -0.03 & 0.02 & -0.03 & -0.01 & -0.04 & 0.02 & 0.02 & -0.15 & 1.00 & \\
\hline \multirow[t]{5}{*}{17} & Industry dummy & 0.03 & -0.06 & 0.01 & 0.01 & -0.05 & 0.06 & -0.01 & 0.14 & -0.42 & 0.04 & -0.12 & 0.02 & 0.41 & 0.08 & -0.01 & 0.02 & 1.00 \\
\hline & Mean & 6.51 & 10.03 & 8.92 & 102.36 & 3.27 & 4.49 & 27.94 & 0.58 & 2.70 & 0.26 & 1.28 & 20.02 & 4.67 & 5.07 & 0.81 & 0.27 & 0.91 \\
\hline & Std. dev. & 6.54 & 23.05 & 23.42 & 678.26 & 13.16 & 16.75 & 320.60 & 0.49 & 7.02 & 0.93 & 6.35 & 0.28 & 1.70 & 1.64 & 0.39 & 0.44 & 0.29 \\
\hline & Min & 0.01 & 0.00 & 0.00 & 0.00 & 0.00 & 0.00 & 0.00 & 0.00 & 0.00 & 0.00 & 0.00 & 19.00 & 0.02 & 0.35 & 0.00 & 0.00 & 0.00 \\
\hline & Max & 84.90 & 100.00 & 100.00 & 8709.28 & 100.00 & 100.00 & 6382.04 & 1.00 & 90.57 & 11.10 & 156.28 & 25.00 & 8.53 & 9.67 & 1.00 & 1.00 & 1.00 \\
\hline
\end{tabular}

Note: Correlation coefficients above $|0.07|$ are significant at the $5 \%$ level (two-tailed). 
Table 3. Random effects GLS regression estimates on the ID - firm performance relationship in the postacquisition period.

\begin{tabular}{|c|c|c|c|}
\hline & Model 1 & Model 2 & Model 3 \\
\hline \multirow[t]{2}{*}{ FSTS } & $0.0367 * *$ & $0.0391 * * *$ & $0.0508 * *$ \\
\hline & $(0.00153)$ & $(0.000208)$ & $(0.00340)$ \\
\hline \multirow[t]{2}{*}{ Acquired shares $(\%)$} & $0.0290 *$ & $0.0307 *$ & 0.0230 \\
\hline & $(0.00272)$ & $(0.00324)$ & $(0.00655)$ \\
\hline \multirow[t]{2}{*}{ FSTS x Acquired shares (\%) } & & $-0.000173 *$ & $-0.000371 * *$ \\
\hline & & $(4.87 \mathrm{e}-05)$ & $(4.95 \mathrm{e}-05)$ \\
\hline \multirow[t]{2}{*}{ FSTS $x$ Business group affiliation } & & & -0.0279 \\
\hline & & & $(0.00520)$ \\
\hline \multirow[t]{2}{*}{ Acquired shares $(\%) \times$ Business group affiliation } & & & 0.0147 \\
\hline & & & $(0.00939)$ \\
\hline \multirow[t]{2}{*}{ FSTS x Acquired shares (\%) x Business group affiliation } & & & $0.000902 * * *$ \\
\hline & & & $(7.46 \mathrm{e}-07)$ \\
\hline \multirow[t]{2}{*}{ Business group affiliation } & 2.355 & 2.548 & 3.206 \\
\hline & $(0.866)$ & $(0.978)$ & $(0.709)$ \\
\hline \multirow[t]{2}{*}{ Marketing intensity } & -0.0474 & -0.0469 & $-0.0434 *$ \\
\hline & $(0.00949)$ & $(0.00799)$ & $(0.00579)$ \\
\hline \multirow[t]{2}{*}{ Technological intensity } & -0.262 & -0.259 & -0.266 \\
\hline & $(0.0772)$ & $(0.0784)$ & $(0.0802)$ \\
\hline \multirow[t]{2}{*}{ Debt/equity } & -0.0226 & -0.0227 & -0.0209 \\
\hline & $(0.0170)$ & $(0.0172)$ & $(0.0165)$ \\
\hline \multirow[t]{2}{*}{ Age } & $-1.006 * * *$ & $-1.001 * * *$ & $-0.936 * *$ \\
\hline & $(0.0143)$ & $(0.00989)$ & $(0.0258)$ \\
\hline \multirow[t]{2}{*}{ (ln)Sales } & 1.127 & 1.142 & 1.016 \\
\hline & $(0.265)$ & $(0.282)$ & $(0.278)$ \\
\hline \multirow[t]{2}{*}{ (ln)Assets } & $-2.435^{*}$ & $-2.444 *$ & $-2.364 *$ \\
\hline & $(0.223)$ & $(0.228)$ & $(0.222)$ \\
\hline \multirow[t]{2}{*}{ Post-2008 period } & $3.773 * *$ & $3.743 * *$ & $3.316^{*}$ \\
\hline & $(0.105)$ & $(0.0855)$ & $(0.272)$ \\
\hline \multirow[t]{2}{*}{ Acquisition episode } & -0.701 & -0.701 & -0.690 \\
\hline & $(0.200)$ & $(0.198)$ & $(0.189)$ \\
\hline \multirow[t]{2}{*}{ Industry dummy } & $10.88^{*}$ & $10.90^{*}$ & $10.72 *$ \\
\hline & $(1.042)$ & $(1.046)$ & $(0.914)$ \\
\hline \multirow[t]{2}{*}{ Constant } & $16.44 * *$ & $16.18 * *$ & $14.67 * *$ \\
\hline & $(0.715)$ & $(0.937)$ & $(0.452)$ \\
\hline Number of firms & 164 & 164 & 164 \\
\hline Number of observations & 716 & 716 & 716 \\
\hline R-squared & 0.6131 & 0.6133 & 0.6163 \\
\hline
\end{tabular}

Note: Robust standard errors clustered at the industry type; $* * * \mathrm{p}<0.01,{ }^{* *} \mathrm{p}<0.05, * \mathrm{p}<0.10$; one-tailed tests for hypothesized variables, two-tailed tests for control variables; All models include firm and year dummies; All independent, moderating and control variables are lagged by one year. 